\title{
Equalizing Resources vs. Retaining Black Political Power: Paradoxes of an Urban-Suburban School District Merger in Durham, North Carolina, 1958-1996
}

\section{Esther Cyna}

Two separate school districts — a city one and a county one-operated independently in Durbam, North Carolina, until the early 1990s. The two districts merged relatively late compared to other North Carolina cities, such as Raleigh and Charlotte. In Durham, residents in both the county and city systems vehemently opposed the merger until the county commissioners ultimately bypassed a popular vote. African American advocates in the city school district, in particular, faced an impossible trade-off: city schools increasingly struggled financially because of an inequitable funding structure, but a merger would significantly threaten fair racial representation on the consolidated school board. This article explores this core tension in historical context by looking at several failed merger attempts from 1958 to 1988, as well as the 1991 merger implementation, against the backdrop of desegregation, economic transition, profound metropolitan changes, and protracted political battles in Durham.

In a 1971 countywide referendum, residents of Durham, North Carolina, overwhelmingly opposed the merger of the city and county school districts, two public school systems that had operated separately since the 1880 s. ${ }^{1}$ The question of merging the two

Esther Cyna is a PhD candidate in History and Education at Teachers College, Columbia University, and doctorante contractuelle at the Université Sorbonne Nouvelle-Paris III in France. She would like to thank archivists at the Durham County Library, Duke University, and the North Carolina State Archives for their guidance as well as Stephanie McCurry, Samuel Jaffe, and the anonymous reviewers at HEQ for their thoughtful feedback.

1 "Charrette Merger Committee Statement," box 4, folder: Political Series: Human resources-Education-Durham School System Merger, 1950s, League of Women Voters of Durham (NC) papers, David M. Rubenstein Rare Book \& Manuscript Library, Duke University (hereafter cited as Durham School System Merger); Reminiscing: A History of Durbam City Schools (Durham, NC: Yarden Publications, the Writer's Group, 1992), 7; and Heather Wiese, "The History of Durham Schools, 1882-1929: Learning from the Past," Digital Durham 2.0, 2011, https://web.duke.edu/digitaldurham/HeatherWiese/index.html. 
systems had surfaced in 1958 and 1968, but voters in both areas had rejected it. ${ }^{2}$

At the time of the 1971 referendum, the Durham city schools had a predominantly black student body, and the local press often pointed to issues of low achievement and poverty in the city district. Although Durham as a whole was known for its thriving black businesses and politically powerful black middle-class, many city residents lived in impoverished black neighborhoods, and continuously fought to improve living conditions, economic and educational opportunities. Poor black residents in Durham had actively mobilized during antipoverty campaigns in the 1960s. ${ }^{3}$ The county schools, located in the surrounding suburbs and in isolated pockets inside the city limits but outside of the city school system, were predominantly white, and increasingly overcrowded. ${ }^{4}$

Historian Jean Bradley Anderson interpreted Durham's segregated landscape as a direct result of "white flight" following school desegregation in the region. ${ }^{5}$ Although token desegregation began in Durham in 1957, white resistance prevented full-scale desegregation until $1970 .{ }^{6}$ As in many metropolitan areas in the country, white residents, incentivized by housing, transportation, and school policies, purchased homes in the suburbs in massive numbers. ${ }^{7}$ This migration often meant that white children would attend predominantly white

${ }^{2}$ Durham School System Merger.

${ }^{3}$ Robert R. Korstad and James L. Leloudis, To Right These Wrongs: The North Carolina Fund and the Battle to End Poverty and Inequality in 1960s America, (Chapel Hill: The University of North Carolina Press, 2009), 176.

4"Durham City Schools Yearly Enrollment, 1954-1976," box 23, folder: Redistricting Study Committee Report, 1979-80, Durham Schools Collection, North Carolina Collection, Durham County Library (hereafter cited as Durham Schools Collection); "Brief on Outside School District but Inside City Limits," Oct. 5, 1971, box 1A, folder: Brief on Outside School District but Inside City Limits, 1971, Stephen C. Harward Papers, David M. Rubenstein Rare Book \& Manuscript Library, Duke University (hereafter cited as Harward Papers).

${ }^{5}$ Jean Bradley Anderson, Durbam County: A History of Durbam County, North Carolina (Durham, NC: Duke University Press, 2011), 414.

${ }^{6}$ David S. Cecelski, Along Freedom Road: Hyde County, North Carolina, and the Fate of Black Schools in the South (Chapel Hill: University of North Carolina Press, 1994), 24-26.

${ }^{7}$ For the policy and political contexts of "white flight," see Kevin M. Kruse, White Flight: Atlanta and the Making of Modern Conservatism (Princeton, NJ: Princeton University Press, 2007). On discrimination in home loans, see Richard Rothstein, The Color of Law: A Forgotten History of How Our Government Segregated America (New York: W. W. Norton, 2017); David M. P. Freund, Colored Property: State Policy \& White Racial Politics in Suburban America (Chicago: University of Chicago Press, 2007); and Kenneth T. Jackson, Crabgrass Frontier: The Suburbanization of the United States (New York: Oxford University Press, 1985). 
schools that did not fall within the scope of desegregation plans. The 1973 Milliken v. Bradley Supreme Court decision limited the possibility of cross-district desegregation, since remedies in these cases could not include districts that had not engaged in intentional segregation as proven in court. ${ }^{8}$

In 1992, the Durham's two districts eventually merged without a referendum. ${ }^{9}$ How? Looking at the history of public opposition to the merger in Durham makes 1992 a surprising turn of events, and an unusual case at a time when many suburban areas that had previously been part of a single, countywide district were seceding from urban districts. ${ }^{10}$ The impulse for the merger came from the Board of County Commissioners, the governing body responsible for allocating state and federal budgets to both school districts, which otherwise operated independently. ${ }^{11}$ Chairman of the Board of County Commissioners William V. Bell believed that the city could never be as attractive as its neighbor Raleigh, given the violence, overcrowding, and low test scores that plagued its inner-city schools. ${ }^{12}$ The state

${ }^{8}$ Milliken v. Bradley, 418 U.S. 717 (1974). For the impact of Milliken, see Gary Orfield and Susan Eaton, Dismantling Desegregation: The Quiet Reversal of Brown v. Board of Education (New York: New Press, 1996), 15, 58. However, school districts in the South have traditionally been large administrative entities that encompass the whole county, which did allow for metropolitan-wide desegregation, for example, Wilmington, Delaware; Nashville, Tennessee; and Charlotte, North Carolina. See Brett V. Gadsden, Between North and South: Delaware, Desegregation, and the Myth of American Sectionalism (Philadelphia: University of Pennsylvania Press, 2013); Ansley T. Erickson, Making the Unequal Metropolis: Desegregation and Its Limits (Chicago: University of Chicago Press, 2016); Matthew D. Lassiter, The Silent Majority: Suburban Politics in the Sunbelt South (Princeton, NJ: Princeton University Press, 2007); and Daniel Amsterdam, "Toward the Resegregation of Southern Schools: African American Suburbanization and Historical Erasure in Freeman v. Pitts," History of Education Quarterly 57, no. 4 (Nov. 2017), 451. Still, many counties in North Carolina had multiple school districts within a single county. For an examination of how consolidation occurred throughout North Carolina in places such as Guilford County, Wake County, and Rocky Mount, see Leslie Honeycutt Barnette, "A Case Study of the Consolidation of Five North Carolina School Districts: Motivations, Processes, and Impact" (EdD. diss., Appalachian State University, 2016).

9 "Durham School Merger Timeline," News \& Observer (Raleigh, NC), July 6, 1997, A10.

${ }^{10}$ On the phenomenon of suburban districts seceding from urban districts since the 1990s, and the legal reasons why this limits desegregation remedies, see Erika K. Wilson "The New School Segregation," Cornell Law Review 102, no. 1 (Nov. 2016), 139-210."

11 "Governance and Administration of the Merger Issues Task Force-Goals and Recommendations," box 5, folder: Merger Issue, 88-89, Durham Schools Collection.

${ }^{12}$ Dawn Baumgartner Vaughan and Zachery Eanes, "Durham Mayor Bill Bell Leaves Office after Four Decades as City, County Leader," (Durham) Herald-Sun, 
legislature passed the merger in July of 1991, despite vocal opposition from residents in the city and county districts. ${ }^{13}$

Much of the city's opposition to the merger stemmed from a fear of diluted black political influence under a merged system, even though the merger seemed to be the only way to equalize resources between the two districts. This tension between seeking equal resources and maintaining political power for the city school district existed and persisted because of historical, structural injustices in school financing schemes, legal constraints, and other policies that reinforced inequalities between urban and suburban areas. Scholars who have documented this paradox argued that desegregation policies came at a greater cost for black administrators, teachers, families, and students. ${ }^{14}$ This article examines the evolution of these dynamics beyond the desegregation years. The constant tension between financial equity and political power, and the changing economic interests that came with the increased influence of the business community, shaped the merger story in Durham. This article builds on recent scholarship about the influence of private-sector actors such as businesses, universities, and urban planners in the history of urban education. ${ }^{15}$ It explores how various actors' understanding of the implications of integration or segregation on the economic

Nov. 29, 2017, https://www.heraldsun.com/news/local/counties/durham-county/ article187038428.html.

${ }^{13}$ Robert Parrish, “Neglected Common Interests: Durham's Struggle to Merge Its City and County Schools" (master's thesis, Duke University, 2001), 2.

${ }^{14}$ About the long road to desegregation in Durham and its costs, see Jack Michael McElreath, "The Cost of Opportunity: School Desegregation and Changing Race Relations in the Triangle Since World War II" (unpublished PhD diss., University of North Carolina, 2002). On student and community experiences of segregation and desegregation in North Carolina, see Vanessa Siddle Walker, Their Highest Potential: An African American School Community in the Segregated South (Chapel Hill: University of North Carolina Press, 1998); and Cecelski, Along Freedom Road.

${ }^{15}$ Stephen Samuel Smith, Boom for Whom?: Education, Desegregation, and Development in Charlotte (Albany: State University of New York Press, 2004). Recent works in this direction include Erickson, Making the Unequal Metropolis; Andrew Highsmith, Demolition Means Progress: Flint, Michigan, and the Fate of the American Metropolis (Chicago: University of Chicago Press, 2015); and Ansley T. Erickson and Andrew Highsmith, "Segregation as Splitting, Segregation as Joining: Schools, Housing, and the Many Modes of Jim Crow," American Journal of Education 121, no. 4 (Aug. 2015), 563-95. In his review of Rothstein's The Color of Law, Destin Jenkins addresses the role of public and private actors in maintaining and exacerbating segregation and the concentration of poverty. He argues that the reason the government, together with private actors, segregated America was the deep-seated racist belief that the presence of black people was detrimental to property value. Destin Jenkins, "Who Segregated America?," Public Books, Dec. 21, 2017, http://www.publicbooks.org/ who-segregated-america/. 
attractiveness of Durham changed over time. The unique political context of Durham, and especially the strength of the city's black political elite, leads us to examine the role of schools in shaping political alliances.

At several moments in time, in 1958, 1968, 1971, 1988, 1991, 1996, referenda and bond issue votes show how the competing interests of different Durham residents clashed over the question of whether or not the two districts should merge. To date, historical accounts of the Durham merger have focused on the racial battles between the predominantly black city district and the white suburban district, and "white flight" in these narratives appears strictly as the racist choice of white residents to relocate away from increasingly black schools. ${ }^{16}$ Moving beyond this narrative, I explore a contentious political situation that developed in the context of a pernicious school financing structure and the changing context of economic-development policies.

Eventually, in 1991, a political alliance between business leaders, county commissioners, and the legislature in Durham managed to bypass the strong resistance that characterized public opinion about the merger, and which crystallized on racial conflict. This article explores how this coalition developed, and why previous attempts could not garner sufficient support. It also highlights continued local concerns over racial representation on school boards and the legacy that previous policies still hold on Durham's educational landscape.

\section{Maintaining a Dual School System: 1958-1968}

From 1958 to 1968 , official policies ensured school segregation in Durham, and merger attempts between the city and county schools failed twice, at a time when the city schools were considered of better quality. ${ }^{17}$ Growth in Durham's overall population brought the question of merging the county and city school systems to the fore in 1958 as city schools, both black and white, were becoming overcrowded. ${ }^{18}$

${ }^{16}$ Parrish, "Neglected Common Interests," 2.

${ }^{17}$ Josephine Clement, the first black woman to sit on the Durham City Board of Education, in 1989 stated, "At that time ... the city system was the prestige system, twenty-five to thirty years ago, and this is true across the nation, not just in Durham. Your affluent, influential people, black and white, lived in the city." Josephine Clement, interview by Kathryn Nasstrom, July 13, 1989, Southern Oral History Program Collection, Documenting the American South, University of North Carolina at Chapel Hill (hereafter cited as Southern Oral History Program Collection).

${ }^{18}$ Population increased from 73,368 in 1950 to 84,642 in 1960 , and then to 100,768 in 1970. Anderson, Durbam County, 449. 
Segregation was part of the conversation but took the form of guarantees that a merged system would still provide "opportunities to operate a segregated system."19 In 1958, four years after the landmark Brown v. Board of Education decision, substantial desegregation in Durham seemed unfathomable. ${ }^{20}$ Engaged in mass resistance, the white population and white leadership fiercely opposed desegregation and devised assignment plans that preserved the racial status quo.

Support for the merger had come from the Board of County Commissioners, which was concerned about the financial efficiency of operating two separate systems, especially as the city grew in size and population. ${ }^{21}$ The League of Women Voters supported the merger as well and emphasized the economic benefits of a merged system, stating, "The Durham community-City and County-would be a more attractive area to new people and industry looking for a home." A member of the League of Women Voters drew a triangle next to this statement, with the letters "RT," referring to the Research Triangle area. ${ }^{22}$ Merger supporters already tied the merger to ideas of economic development, as they would in later years, but the argument did not garner enough political support to implement change.

The merger question was attached to a bond issue in November 1958 , which was defeated by a ten-to-one margin. ${ }^{23}$ In fact, the question of taxes dominated the merger debate that year, as combining the two entities would have triggered a forty-cent increase on each one hundred dollars for county schools in order to match the supplemental city tax. ${ }^{24}$ City schools seemed to fare better than the county schools,

19“Arguments Made Against Consolidation," 1958, Durham School System Merger, 11.

${ }^{20}$ Reacting to the Supreme Court ruling over Brown in 1954, the North Carolina governor gathered a special advisory committee on education, whose report stated the following priorities: "1. Preservation of public education in North Carolina 2. Preservation of the peace throughout North Carolina. The Committee is of the opinion that the mixing of the races forthwith in the public schools throughout the state cannot be accomplished and should not be attempted." Thomas J. Pearsall, et al., "Report of the Governor's Special Advisory Committee on Education," (Raleigh, NC: Governor's Special Advisory Committee on Education, Dec. 1954), 312.

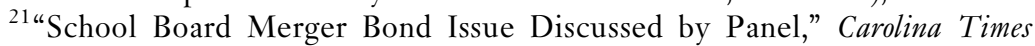
(Durbam, NC), Oct. 9, 1971, 3A.

22 "School Consolidation," Durham School System Merger, 1. On economic arguments behind white support for desegregation leading to and after Brown, see Derrick A. Bell, "Brown and the Interest-Convergence Dilemma," in Derrick Bell, ed., Shades of Brown: New Perspectives on School Desegregation, (New York: Teachers College Press, 1980).

${ }^{23}$ Bell, "Brown and the Interest-Convergence Dilemma," 2.

24 "Arguments Made Against Consolidation," Durham School System Merger, 2 
and the city school board was unwilling to concede control of the city system. County residents resisted the tax.

The themes of segregation, economic development, and taxes would remain central to merger debates for three decades, but the evolving context of Durham changed the framing of these issues. During the 1958 to 1968 decade separating the two crucial votes in Durham, there was much talk about the role of segregation or integration for the economics of the South, but political and business interests at the local scale failed to align. ${ }^{25}$

In 1968, a bond proposal ignited heated debate once again. Education had changed in Durham since the previous merger attempt, and many affluent families had moved to the suburbs in fear of courtmandated desegregation. This reduced the tax base for the city schools. A committee of the interracial Interdenominational Ministerial Alliance advocated for the merger and explicitly criticized the property tax system because it deepened inequalities: "It is imperative that the city and county school systems be consolidated. ... It is necessary for city and county government groups to enlarge the tax base by means other than the traditional one of increasing the property tax, to assure adequate financing." 26

The system of school financing created a vicious cycle: as the city's tax base decreased, the city needed to increase its tax rate, which could drive people away. Two Durham residents wrote to the city's Board of Education to highlight this issue:

I am a white person, a social worker by profession. My husband is a psychology professor at Duke. Both of us are concerned about the decline of our cities, which are quickly becoming negro slums. The approval of yesterday's bond issue would have added to the exodus of affluent whites to the county, where they could attend the shiny, new, segregated schools. ${ }^{27}$

The bond issue failed because it proposed a tax increase. ${ }^{28}$

Business leaders involved in Durham's economic development supported the merger. George Watts Hill, a high-profile businessman

${ }^{25}$ In 1955, black Durham banker John H. Wheeler linked the desegregation of North Carolina to its economic well-being, stating, "Racial segregation in the public schools and in employment is producing a burden which is becoming too heavy for the economy of our state." The Robesonian (Lumberton, NC), Feb. 23, 1955, 1.

${ }^{26}$ Social Action Committee of the Durham Ministers Association to the Durham City Board of Education, Feb. 12, 1968, box 1A, folder: Consolidation Study I, 1968, Harward papers.

${ }^{27}$ Joan Batwineck to Carlie Sessoms, Jan. 31, 1968, box 1A, folder: Consolidation Study I, 1968, Harward papers.

${ }^{28}$ Durham Ministers Association Social Action Committee to the Durham City Board of Education. 
who was instrumental in creating the Research Triangle Park (RTP), a scientific hub that would later bring tremendous economic growth to the region, was extremely disappointed with the 1968 failure and wrote to the Durham City Board of Education: "If three systems can be merged in Gaston County and a $\$ 20$ million bond issue approved, it would seem to me that the least Durham could do would be to put two systems together and approve a reasonable bond issue." ${ }^{29}$ Hill was also a proponent of school integration and believed that segregation hindered progress in the South. He tied racial harmony, or the pretense of it, to greater attractiveness for the region. ${ }^{30}$ Many business leaders in Durham would continue to support the merger for decades to come, although the industrial landscape had changed, and economic incentives revolved on a different understanding of development in later decades.

The February 1968 defeat of the school bond issue prompted the Division of School Planning of the North Carolina Department of Public Instruction to look into the Durham districts. ${ }^{31}$ The state agency asked the two districts to form a study group. ${ }^{32}$ Representatives from the city and county boards sat on the study group and examined operations, planning, finance, student assignment, and school construction. The fact that the study group was all white raised serious concerns about black representation and called the group's recommendations into question. ${ }^{33}$ Department of Public Instruction official J. L. Pierce was astounded by the level of disagreement in Durham and pointed out to the Durham School Consolidation Study Committee, which included city and county boards as well as the county commissioners, that representatives from the two districts were not ready to make any common decisions, not even on the composition of the study group itself. ${ }^{34}$ The study committee did not lead to palpable changes, but it built momentum for a merger proposal three years later.

${ }^{29}$ George Watts Hill to Carlie Sessoms, Walter Dozier, and Mrs. Willard Marley, Feb. 29, 1968, box 1A, folder: Consolidation Study I, 1968, Harward papers.

${ }^{30}$ James Cobb, The Selling of the South: The Southern Crusade for Industrial Development, 1936-90 (Urbana: University of Illinois Press, 1993).

${ }^{31}$ Minutes, Feb. 27, 1968, Durham Schools Consolidation Study Group, box 1A, folder: Consolidation Study I, 1968, Harward papers (hereafter cited as Consolidation Study Group).

${ }^{32}$ Minutes, March 12, 1968, Consolidation Study Group. Group.

${ }^{33}$ J. H. Wheeler,to Mrs. Willard Marley, April 5, 1968, Consolidation Study

${ }^{34}$ Minutes, March 26, 1968, Consolidation Study Group; and Cornelia Olive, "Group Said Not Ready for Study of Merger," Durham Morning Herald, March 27, 1968, newspaper clipping, Consolidation Study Group. 


\section{Curtailing Desegregation: 1971-1988}

In 1971, the Board of County Commissioners again pushed for a referendum, with support from several groups highlighting the economic rationale behind the merger, including the Chamber of Commerce and faculty at Duke University. ${ }^{35}$ But once again the Durham population overwhelmingly opposed the proposal and chose to maintain the boundaries between the urban and suburban districts. The three years that separated the 1968 and 1971 referenda had witnessed drastic changes in Durham, marked by court-mandated desegregation that overhauled the schools, with new assignment plans implemented in $1970 .{ }^{36}$

During the height of desegregation, from 1971 to 1974, the merger of the county and city school was again struck down-by vote, by the school boards, and by the courts. Schools began to resegregate almost as soon as the desegregation plan was implemented. For example, at Hillside, the historically black high school, black students represented 69 percent of the student body in 1970 when the plan was implemented and 78 percent in $1973 .{ }^{37}$

The 1971 referendum had a salient racial dimension. Press coverage highlighted the racial implications of the merger vote, which, as the Carolina Times argued, would trigger white outmigration, and in the context of racial discrimination, would run the risk of diverting resources away from the city schools: "Without merger, the city school system will soon become an almost totally black system. ... The ensuing racial imbalance will nullify any educational improvements gained by Durham blacks, and end in an erosion of city school educational standards." 38 The implications of the merger defeat, then, were clear, and the school districts would gradually become more segregated, not as a dual system within school district boundaries, but as two separate entitiesone predominantly white, and one black. ${ }^{39}$ In the early 1970s, Durham

35 "Why the Durham Chamber of Commerce Board of Directors Are FOR School Bonds and FOR Merger," box 2, sub-folder 1: Merger, 1971, Harward papers; and "League Supports Merger and Bond School Proposals," box 2, sub-folder 1: Merger, 1971, Harward papers; Michael McCall, "School Boards Take Stand to Support Bonds Merger," Durbam Morning Herald, Oct. 10, 1971; and "Chamber Endorses Merger of Schools," Carolina Times (Durham, NC), Oct. 2, 1971, 8B.

${ }^{36}$ Senior High School Assignment Plan, Aug. 1970, box 2, folder: Maps, Harward papers; and Sarah Reckhow, "What We Considered the Best': Making the Best of Integration at Hillside High School" (master's thesis, Harvard College, 2002), 53.

${ }^{37}$ Wheeler v. Durham City Board of Education, 585 F.2d 618 (4th Cir.1978).

38 "Chamber Endorses Merger of Schools."

${ }^{39}$ James Vaughan, "Durham School Bond, Merger Defeated: Black Voters Pleased Over Election Result" Carolina Times (Durbam, NC), Nov. 6, 1971, 1. Unofficial returns indicated that the vote against the merger was 14,710 to 4,698 . 
city's population was approximately 50 percent black and 50 percent white, and the county's population was 86 percent white. ${ }^{40}$

The issues that segregation raised in terms of tax base and resources were even more patent in racially segregated enclaves called the "city out" areas, which existed within the city boundaries but were operated by the county school system. As the City of Durham grew, residents in the areas within the expanded city boundaries had the opportunity, once the areas were officially annexed by the city, to choose whether to be attached to the city or county school system. ${ }^{41}$ This was possible because the city had voted a supplemental tax for schools in 1932, which created a fiscal discrepancy between the city and county districts. Starting in 1932, then, areas annexed into the city of Durham were not automatically annexed to the city school district. Residents of the annexed areas could vote to remain part of the county school district, thereby avoiding the city supplemental tax. ${ }^{42}$

Until 1955, all annexed areas were incorporated into the city school district even though the city's supplemental school tax was twice as much (forty cents per $\$ 100$ valuation in the city versus twenty cents in the county district). ${ }^{43}$ Starting in 1955 , notably a year after Brown v. Board of Education, this pattern was abruptly interrupted, and expansion of the Durham city limits only rarely translated into school city district inclusion.

In 1965 , only 10 percent of suburban areas annexed by the city voted to join the city school district. As a result of continued expansion, in 1971 , only 46 percent of the Durham city area was operated by the city school district. This went on for years (see Figure 1).

These "city-out" enclaves presented the most visible expression of segregation along institutional boundaries and highlight the use that white citizens made of existing policies to curtail meaningful desegregation. A 1971 study by a group of attorneys stated: "The 'city-out' enclaves preclude racially balanced schools within the city of Durham and establish built-in racial discrimination within the city itself." ${ }^{44}$ As this example shows, schools did not merely reflect housing

${ }^{40}$ Sarah Hamilton, "Class Dimensions of Racial Politics: A Case Study of Durham, NC, School Desegregation, 1969-74" (honors paper, Duke University, 1999), 134.

41 "Brief on Outside School District but Inside City Limits."

${ }^{42}$ Wheeler v. Durbam City Board of Education, 379 F. Supp. 1352 (M.D.N.C. 1974), 1362-1363; North Carolina General Statutes G.S. 160A-58.10 et seq., Session Laws, (Raleigh, NC: General Assembly, 1985), Ch. 744, \$ 1. On annexation laws in North Carolina, see Russell M. Smith, "An Examination of Municipal Annexation Methods in North Carolina, 1990-2009." Southeastern Geographer 52, no. 2 (2012), 164-82.

43 "Brief on Outside School District but Inside City Limits," 6.

44 "Brief on Outside School District but Inside City Limits," 13. 


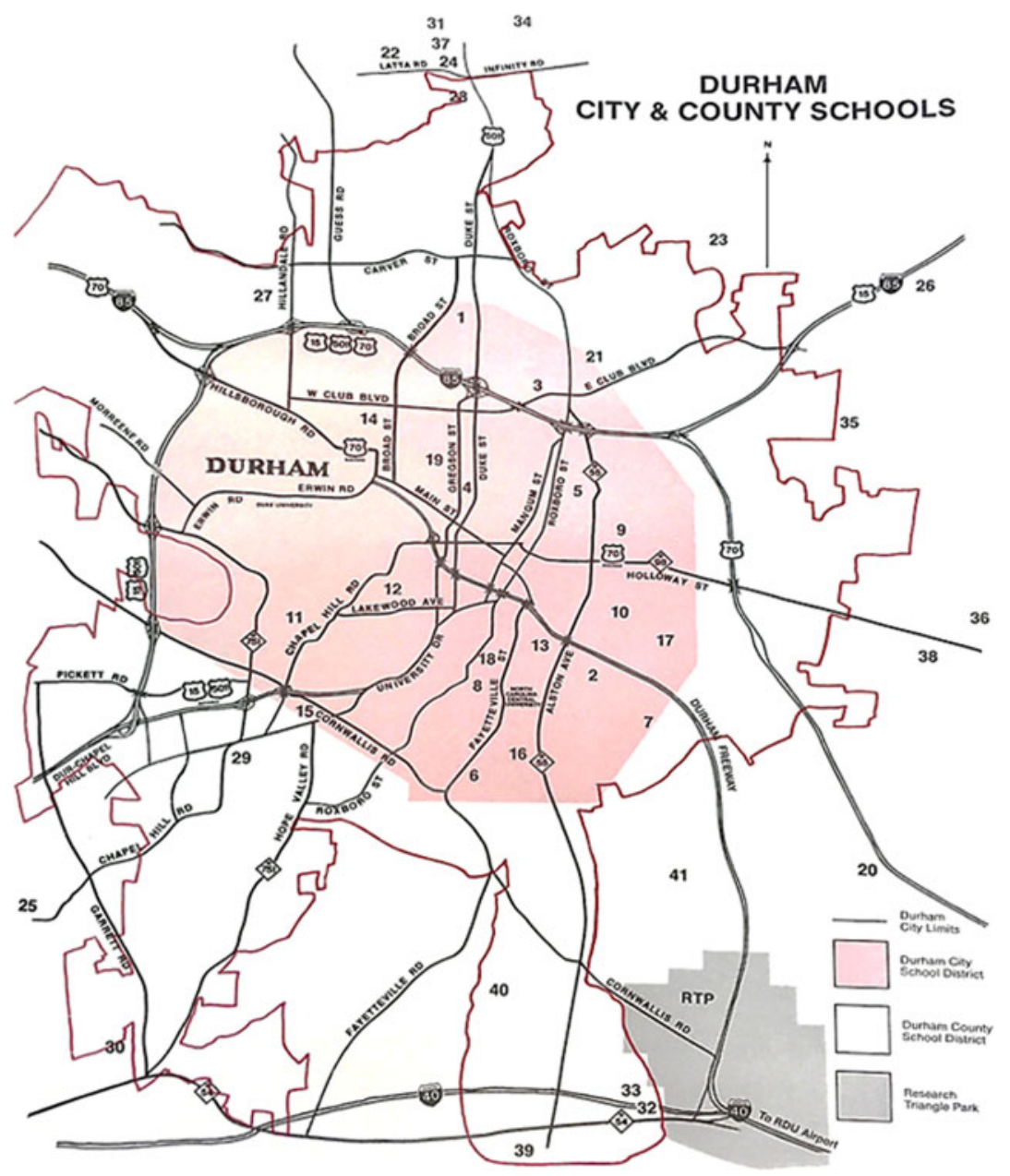

Figure 1. City and County School Districts, 1988-1989. Because of annexation laws and opt-out mechanisms, the city school system only covered the inner core (shaded area) of the city of Durham. The rest was operated by the county system, even within city limits. ("Public Education: Durham, 1988-1989," box 75, folder: Durham Board of County Commissioners Merger Plan, Feb. 1992, 9, Durham Public Schools Collection, North Carolina Collection, Durham County Library.) 
segregation, they were segregative forces themselves. These separate pockets only existed for the schools: city-out residents enjoyed city services in terms of utilities and transportation. ${ }^{45}$

The enclaves had deep financial implications. The city schools could not levy taxes for the city-out areas, even as all city residents, including residents of the city-out areas, voted in city school board elections - city-out residents had political power over the city schools but did not contribute to them financially, and their children attended the whiter, wealthier county schools. As the city grew, its schools became increasingly poorer than the county schools, which collected more money from local taxes. ${ }^{46}$ This specific arrangement shows that the fiscal disadvantage of urban schools did not stem from white migration only but from many forms of fiscal policy-making that granted greater choice to white residents regarding the school system to which they wanted to contribute their tax money and send their children. The statutes also gave city-out residents more political weight in school board elections.

In the summer of 1971, a special community relations group called the Save Our Schools (SOS) Durham Charrette addressed the issue of racial integration in Durham. ${ }^{47}$ The two Charrette cochairs embodied Durham's intense racial polarization: Ann Atwater was a local black advocate and C. P. Ellis was the leader of the local chapter of the Ku Klux Klan. ${ }^{48}$ Ann Atwater had been a community activist since the 1960s, when she became a central force in the war on poverty efforts in Durham as part of Operation Breakthrough, a war-on-poverty effort to mobilize poor Durhamites. ${ }^{49}$ At the time, Ellis believed that the Klan was a legitimate actor in local affairs, and he made a habit

${ }^{45}$ The annexation process, starting in 1957 , extended city services such as fire protection, water, sewer services, and more to all annexed areas. "Brief on Outside School District but Inside City Limits," 2-5.

${ }^{46}$ In 1972, 28 percent of the Durham County schools budget came from local funds, which was much higher than the state average of 20 percent. Decade Report: 10 Years of Progress, 1972-73 to 1982-83, Durham County Schools, box 27, North Carolina Collection, Durham County Library.

${ }^{47}$ The goal of the Charrette was to involve the local community in identifying problems and designing solutions. Teresa Leonard, "Civil Rights Activist and Klan Leader Attacked Problem from Opposite Sides," News \& Observer (Raleigh, NC), June 24, 2016, https://www.newsobserver.com/living/liv-columns-blogs/past-times/ article $85852732 . h t m l$.

${ }^{48}$ Parrish, "Neglected Common Interests," 25. Defying all odds, Ellis and Atwater became close friends. The story of their friendship is at the center of Osha Gray Davidson's book The Best of Enemies: From Prejudice to Friendship in the Post CivilRights South (New York: Scribner, 1996.

${ }^{49}$ Korstad and Leloudis, To Right These Wrongs, 181-184. 
of attending city council meetings in Durham. ${ }^{50}$ Ellis recalls the Charrette days as a transformative experience in which he realized that black people and poor white people all suffered from the difficulties urban schools faced. ${ }^{51} \mathrm{He}$ left the ten-day open Durham Charrette with a completely different understanding of racial inequalities, became a civil rights activist and helped organize integrated unions for Durham workers.

After several days of debate around school integration, including the question of the merger, the Charrette conducted a public opinion survey. Results indicated that Durham residents would favor a merger at the polls. ${ }^{52}$ In November 1971, however, only 4,698 voted in favor of the merger, and 14,710 people opposed it. ${ }^{53}$ Opposition came from the county and city population, from black and white voters, albeit on different grounds. The white population feared busing, an increase in tax rate for the county, and a decrease in educational quality. ${ }^{54}$ Black Durhamites, including Lavonia Allison of the Durham Committee on the Affairs of Black People, denounced a white agenda to seize control of all schools. ${ }^{55}$ Fears of losing job security under a merged system that would potentially discriminate against black teachers and administrators also alarmed black Durhamites. ${ }^{56}$ John Wheeler, leader of the Durham Committee on Negro Affairs, also pointed out that the bond proposal would disproportionately benefit county schools for school construction, with the city schools receiving only $\$ 5$ million out of the $\$ 17.5$ million that would have resulted from the bond issue. ${ }^{57}$

The question of political power for different racial groups was a linchpin in the merger debate. In the early 1970s, school board representation was beginning to shift. The city was somewhat unique: contrary to what occurred in many other places, it had not closed its

${ }^{50}$ About the political tradition of the KKK, which its members promoted as a civic organization, see Linda Gordon, The Second Coming of the KKK: The Ku Klux Klan of the 1920s and the American Political Tradition (New York: Liveright Publishing, 2017).

${ }^{51}$ Studs Terkel, "Why I Quit the Klan'-An Interview with C. P. Ellis," Southern Exposure 8, no. 2 (Summer 1980), 47-52.

52 "School Opinion Survey Results," 1971, Durham School System Merger.

${ }^{53}$ Vaughan, "Durham School Bond, Merger Defeated."

${ }^{54}$ Reckhow, "What We Considered the Best," 108.

${ }^{55}$ James O'Reilly, "Hearing Attracts Big Crowd," Durbam Morning Herald, Oct. $31,1974,1 \mathrm{~A}$.

${ }^{56}$ Reckhow, "What We Considered the Best," 108; Parrish, "Neglected Common Interests," 36-38; and O'Reilly, "Hearing Attracts Big Crowd." On the consequences of desegregation for black teachers, see Michael Fultz, "The Displacement of Black Educators Post-Brown": An Overview and Analysis," History of Education Quarterly 44, no. 1 (Feb. 2004), 11-45.

${ }^{57}$ Vaughan, "Durham School Bond, Merger Defeated." 


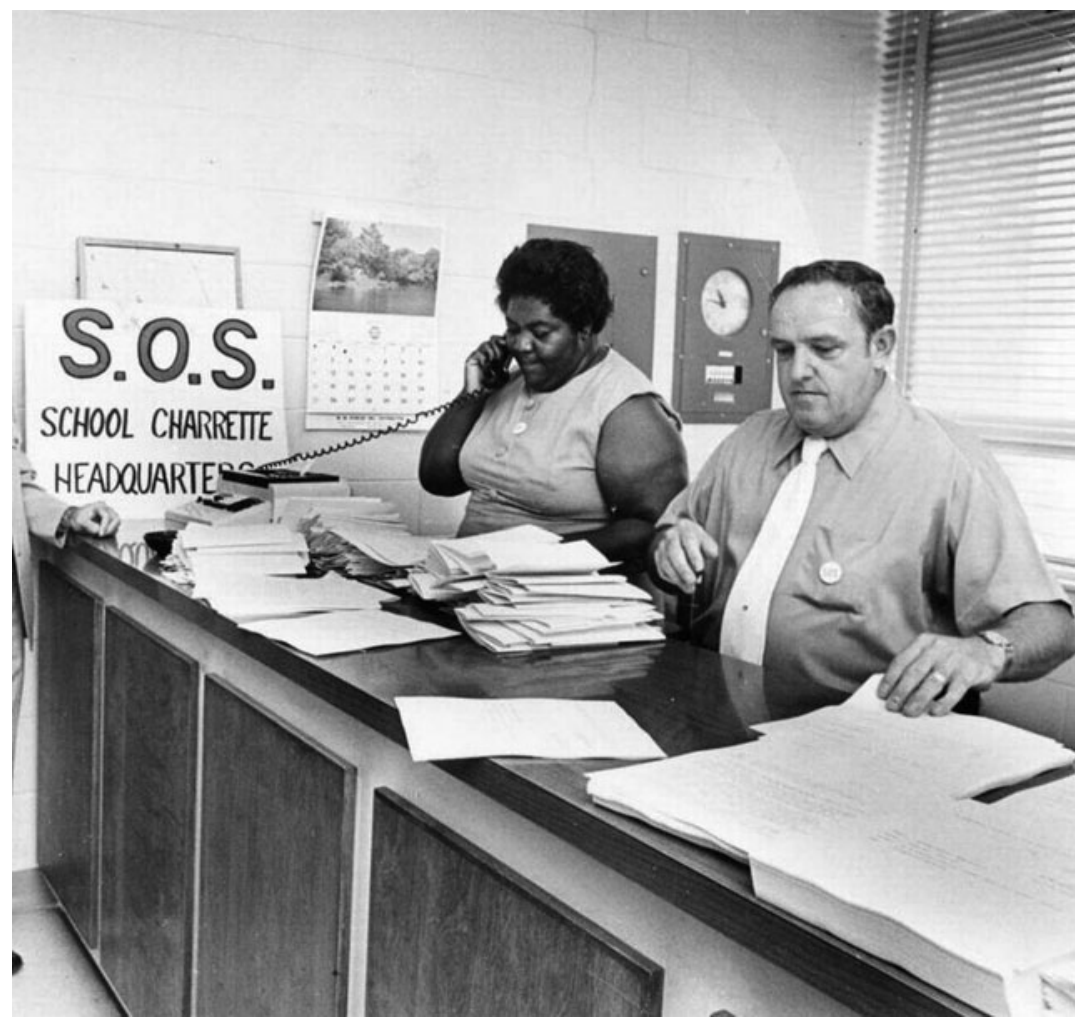

Figure 2. Ann Atwater, a leading advocate for African Americans in Durham, and C. P. Ellis, a former member of the KKK, were working as co-chairs of the Durham Charrette in 1971. (Jim Thornton, "SOS Charrette," July 21, 1971, Durham Herald Co. Newspaper Photograph Collection \#P0105, North Carolina Collection Photographic Archives, Wilson Library, University of North Carolina at Chapel Hill.)

historically black schools as a result of desegregation. ${ }^{58}$ Many black Durhamites advocated against the merger at a time when they were gaining influence on the city school board, which had previously been all white and all male. Josephine Clement became the first black woman on the City Board of Education in 1973, when the Board was still appointed, and she was elected chair in 1978 with the first city elections. In 1975, four out of five members on the Board were

${ }^{58}$ Out of the 223 black high schools that operated before Brown v. Board in North Carolina, only 13 remained open by 1972. Frederick A. Rodgers, The Black High School and Its Community (Lexington, MA: Lexington Books, 1975), 70. 
black. ${ }^{59}$ Clement fiercely opposed the merger in 1971 - she was, in her words, "chauvinistic about the city system." By 1989, however, she supported the merger, changing her mind because of the stark inequalities between the two districts. ${ }^{60}$ The potential dilution of black control over the city school district was a core theme throughout the merger debates, as the potential merger threatened job security for black teachers and administrators as well as the district voting structure of the school board elections. ${ }^{61}$

After the merger was struck down at the polls in 1971, city school board member Stephen Harward attempted to convince the county and city school boards to bypass the vote and implement the merger anyway, but to no avail. ${ }^{62}$ Others, who were equally convinced of the necessity of a merger to achieve racial balance and to reduce the increasing inequalities between the two systems, turned to the court. The civil rights attorneys who had litigated the local desegregation lawsuit in 1961 on behalf of black students in the Durham city schools filed a new motion against the two school boards on December 18, 1972.63 Their case, Wheeler v. Durham City Board of Education (1974), alleged that the concentration of the white population in a separate district in the suburbs and in city enclaves was a "new version of segregation." ${ }^{64}$ Merging was, in the plaintiffs' view, "the only way to offer stable desegregation and equality of educational opportunity to the residents of the heavily black and poor city school district." ${ }^{65}$ The judge ruled against the plaintiffs, stating that they had not provided sufficient evidence of the county district's intent to segregate.

The Wheeler decision had consequences that would shape the metropolitan landscape of Durham for decades to come in a way that mirrors federal developments on these issues. In 1973, in San Antonio v. Rodriguez, the Supreme Court justices upheld the school finance system in Texas, despite the irrefutable inequities between wealthy and

${ }^{59}$ Clement, interview, July 13, 1989.

${ }^{60}$ Josephine Clement, interview by Kathryn Nasstrom, August 3, 1989, Sourthern Oral History Program Collection.

${ }^{61}$ Crystal Sanders recently explored how a Head Start program in Mississippi, as part of the War on Poverty, provided black women in the state with opportunities for political activism. Crystal R. Sanders, A Chance for Change: Head Start and Mississippi's Black Freedom Struggle (Chapel Hill: University of North Carolina Press, 2016).

${ }^{62}$ Parrish, "Neglected Common Interests," 38.

${ }^{63}$ Wheeler v. Durham City Board of Education.

${ }^{64}$ James O'Reilly, "Merger, 'City-Out' Items Dropped From School Suit," Durham Morning Herald, Nov. 26, 1974, 1A.

${ }^{65}$ O'Reilly, "Merger, 'City-Out' Items Dropped from School Suit." 
poor districts to which it led. ${ }^{66}$ In 1974, the Supreme Court ruled in Milliken v. Bradley that desegregation remedies could not involve separate school districts - in this case, both urban and suburban districts in Detroit, Michigan - unless plaintiffs showed that both school districts intentionally contributed to segregation in the inner city schools. ${ }^{67}$ Milliken significantly curtailed desegregation across different districts. Law and education scholar James Ryan drew a comparison between school finance and desegregation cases, indicating that both reinforced the boundaries between cities and suburbs and both announced what he argues has been the most powerful paradigm of post-1973 metropolitan education reform: "Save the cities, but spare the suburbs." ${ }^{8}$

In the middle of these major federal cases, the Wheeler case paralleled the Supreme Court's reasoning. In 1974, the district court stated that segregation in Durham could not be attributed to the actions of city officials, school boards, or official policies, but resulted from a "variety of complex and interrelated social factors which defy tidy cause and effect analysis." 69 This description of district lines erases the authority of school districts to alter their assignment plans as well as the mechanisms that allowed city-out areas to choose the white county system regardless of geographical location, and inconsistently when compared to other city services. Milliken, Rodriguez, and Wheeler belong to a long list of court decisions that refused to see the history of school boundaries as a history of intentional segregation and the hoarding of resources. ${ }^{70}$ Yet school district lines, far from being accidental, are constructed boundaries that create channels for

${ }^{66}$ San Antonio Independent School District v. Rodriguez, 411 U.S. 1 (1973). For an analysis of the history and significance of the case, see Paul A. Sracic, San Antonio v. Rodriguez and the Pursuit of Equal Education: The Debate over Discrimination and School Funding (Lawrence: Kansas University Press, 2006). The justices argued that the financing scheme, although it led to gross inequalities, had a rational relationship with the legitimate state purpose of local control: fiscal control within school district boundaries.

${ }^{67}$ Milliken v. Bradley.

${ }^{68}$ James Ryan, Five Miles Away, a World Apart: One City, Two Schools, and the Story of Educational Opportunity in Modern America (New York: Oxford University Press, 2010), 178.

${ }^{69}$ Wheeler v. Durbam City Board of Education, 1369.

${ }^{70}$ These decisions have subscribed to and reinforced the myth of de facto segregation (segregation as a symptom of individual preferences and behaviors), which scholars have worked to deconstruct by showing that structural forces and policies shape metropolitan spaces. See Arnold R. Hirsch, Making the Second Ghetto: Race and Housing in Chicago, 1940-1960 (New York: Cambridge University Press, 1983); Thomas J. Sugrue, The Origins of the Urban Crisis: Race and Inequality in Postwar Detroit (Princeton, NJ: Princeton University Press, 1996); John L. Rury and Jeffrey E. Mirel, "The Political Economy of Urban Education," Review of Research in Education 22 (Jan. 1997), 49-110; and Michael Glass, "From Sword to Shield to 
isolating tax money and crystallizing power, and that have the effect of limiting opportunities for certain students-disproportionately poor students of color. ${ }^{71}$

Faculty and administrators at Duke University, an elite institution in Durham, were divided after the merger failed at the polls. ${ }^{72}$ Perceiving the degradation of city schools, some faculty members raised serious concerns about the attractiveness of Duke for potential recruits. ${ }^{73}$ In June 1973, Chancellor John O. Blackburn proposed establishing a special private school for faculty children, and his plan for a "demonstration school" received support from Terry Sanford, then President of Duke University. ${ }^{74}$ Several professors spoke in favor of the proposed private school. Sam Gross, a chemistry professor, testified at a university forum that the need for a private school for children of Duke professors was "extremely urgent," and claimed that his children suffered in Durham public schools because "they [were] excluded from the black society." $75 \mathrm{He}$ argued that the University was losing faculty members because of the poor public schools, although others challenged his statement. ${ }^{76}$ The plan sparked a heated debate in Durham, with school board members in the city and county districts condemning Duke's secessionist reaction. ${ }^{77}$ Mrs. Dillard Teer, who sat on the Durham City School Board, warned that the Duke private school would "certainly make the [public] schools poorer." 78 Some Duke faculty members also opposed creating a private school, and called it "paternalistic, isolationist, and potentially racist" in the university's newspaper, although they remained anonymous. ${ }^{79}$ Donald Fluke, who had actively promoted the merger in 1971,

Myth: Facing the Facts of De Facto School Segregation," Journal of Urban History (Nov. 2016), 1-30, DOI: 0096144216675473.

${ }^{71}$ For the case of segregated schools in the early 2000s in Hartford, Connecticut, see Susan E. Eaton, The Children in Room E4: American Education on Trial (Chapel Hill, NC: Algonquin, 2007).

${ }^{72}$ Parrish, "Neglected Common Interests," 45.

${ }^{73}$ Ann Pelham, "Duke Planning School for Children of Faculty," Summer Chronicle (Durbam, NC), Jun. 4, 1973, 1.

${ }^{74}$ Pelham, "School Planned for Faculty Children," The Summer Chronicle, Jun. 4, 1973,3 .

${ }^{75}$ Ann Pelham, "Faculty Action Fails to Support School Proposal," The Summer Chronicle, Jun. 11, 1973, 4.

${ }^{76}$ Pelham, "Faculty Action Fails to Support School Proposal," 1.

${ }^{77}$ Pelham, "Duke Planning School for Children of Faculty," 1.

${ }^{78}$ Pelham, "School Planned for Faculty Children," 3.

${ }^{79}$ Pelham, "Duke Planning School for Children of Faculty," 1. 
fiercely opposed Blackburn's plan, which was abandoned as a result of the controversy. ${ }^{80}$

What faculty members at Duke perceived was a sharp decline in the quality of public schools, with mixed arguments about the increasing "minority" population and deteriorating standards, and the murky causal arguments of the debate underline persisting racist assumptions about educational standards with an increased population of students of color. Yet schools were increasingly suffering from reduced funds.

Fiscal policies continued to disadvantage urban schools in Durham, with two separate districts and city-out legislation entrenching the inequities. But advocates for consolidation faced strong political obstacles in the 1970s. As opposed to county commissioners and business groups, neither the county nor the city school boards supported the merger. These political obstacles were greater in Durham than other areas, for example, in Charlotte, where the city and county districts merged through a referendum as early as 1960, under the leadership of civic leaders who were concerned about administrative efficiency, and in Raleigh, where the two districts merged in $1974 .{ }^{81}$ In Charlotte and Raleigh, political interests already closely aligned with business agendas, especially around economic development. ${ }^{82}$

\section{Consolidation: 1988-2001}

During the 1980s, Durham city schools were plagued with underfunding, decreasing enrollment, low academic achievement, and school violence. ${ }^{83}$ The gradually declining enrollment in the city schools had a significant impact on school budgets, since about two-thirds of the city budget came from the state on a per capita basis. ${ }^{84}$

${ }^{80}$ Parrish, "Neglected Common Interests," 53.

${ }^{81}$ Smith, Boom for Whom, 59.

${ }^{82}$ McElreath also identifies political climate as the main difference between Durham and Raleigh: "Political, civic, and business leaders in Raleigh and Wake overrode their neighbors and merged the systems without a referendum in 1975. In Durham leaders also worried about the long-term economic and social effects of a deteriorating urban core, but they could not muster the will to force the issue against voters' wishes." McElreath, "The Cost of Opportunity," 12.

83 "Redistricting Study Committee Report," box 23, folder: Redistricting Study Committee Report, 1979-80, Durham Schools Collection; and "Report for Final Recommendations of the Durham Merger Issues Task Force in April 1989," box 5, folder: Merger Issue, 88-89, Durham Schools Collection.

84 "Report of the Committee to Study the Utilization of Attendance Centers: Durham City Schools," Feb. 1980, box 23, folder: Redistricting Study Committee Report, 1979-80, Durham Schools Collection. 
The district lines between city and county districts also prevented any meaningful integration of schools. ${ }^{85}$ In 1988 , the county schools were 68 percent white, and the city schools were 89 percent students of color. ${ }^{86}$ As in many parts of the country, the city's inner core had high levels of poverty, which, coupled with the structural underfinancing of schools, led to a dire situation and to a growing negative image for the city, which had the characteristics of an urban "ghetto." 87 The 1980 census indicates that the county school district had an income level almost twice that of the city district. The city school district poverty level was among the highest in the state, and was three times that of the county.

The reputation of the city schools worsened, and by 1988 they had the highest dropout rate in the state of North Carolina. ${ }^{88}$ Looking back at the situation in the 1980s, William Bell, later Durham's first black mayor, summarized the situation: "The county (schools) were white, well to do. The city was black, reduced lunch." ${ }^{89}$

The North Carolina legislature pressured districts across the state to consolidate to increase administrative and financial efficiency. ${ }^{90}$ In May 1988, the Board of County Commissioners in Durham formed the Merger Issues Task Force to conduct a study and issue recommendations

\footnotetext{
85 "Report of the Committee to Study the Utilization of Attendance Centers: Durham City Schools."

86 "Report to the Durham City Board of Education from the System-Wide Advisory Board: Equal Opportunity and Excellence," box 75, [unprocessed], 6, Durham Schools Collection.

${ }^{87}$ On the racial dimension of the image of the "ghetto," see Wendell E. Pritchett, Brownsville, Brooklyn: Blacks, Jews, and the Changing Face of the Ghetto (Chicago: University of Chicago Press, 2002); and Rothstein, The Color of Law. In Durham, press coverage referring to downtown uses the same imagery. See Cornelia Olive, "Plight of Project III," Durham Morning Herald, May 10, 1970, 6A.

${ }^{88}$ In 1984, Durham newcomers described their conversation with longtime residents: "The city schools? Forget it! If you want public schools, you have to buy in the county." Catherine Petroski, "Why We Chose Private Schools," Christian Science Monitor, Feb. 10, 1984, https://www.csmonitor.com/1984/0210/021054.html, para. 7; and "Report to the Durham City Board of Education," 6.

89 "Reduced lunch" here refers to a measure of poverty for children. Dawn Baumgartner Vaughan and Zachery Eanes, "At 31, Bill Bell said, 'If you can't beat 'em, join 'em.' He did, and changed Durham," https://www.heraldsun.com/news/ local/counties/durham-county/article186928108.html, para. 11.

${ }^{90}$ According to Barnette, in the 1980s, 1990s, and 2000s, "the State Legislature had created a climate in which Boards of County Commissioners were encouraged to consolidate school systems in counties where more than one system existed." "A Case Study of the Consolidation of Five North Carolina School Districts," 109. In 2004, the North Carolina legislature announced that it would only fund one school system per county, but backed off of the proposal a year later.
} 
regarding a potential merger. ${ }^{91}$ The Task Force's goals did not directly address the state legislature's efficiency concerns and instead had more community-specific priorities. Governance was central to the 1988 study: its first stated goal addressed racial imbalance in Durham, not in terms of the racial composition of student bodies in schools but in terms of school board representation. ${ }^{92}$ With a growing sense that black interest groups dominated the city schools, the merger question had been enmeshed in racial tension for years.

The Task Force's second goal tackled taxes, another major issue that had long been an obstacle to the merger. ${ }^{93}$ The suburban district had a much larger tax base than the urban district, a pattern that mirrored many other metropolitan areas in the United States. ${ }^{94}$ The urban district had a higher tax rate, but could not make up for its smaller tax base, and it had additional spending needs, including language and dropout-prevention programs. ${ }^{95}$ The parallel systems relied on an inequitable funding structure that deepened disparities in wealth. In 1986, one cent of tax in the city yielded about seventeen dollars for a city student, while one cent in the county yielded about thirty-one dollars per student. ${ }^{96}$

Awareness of these structural inequities did not translate into public support for change. Because its recommendations stressed the importance of active community participation, the Task Force planned on holding a new merger referendum. ${ }^{97}$ But the Durham

91 "Facing the Future of Our Schools: Excellence and Equal Opportunity for Durham's Children: Appendices to the Final Report and Recommendations, Presented to the Durham County Board of Commissioners, Merger Issues Task Force, May 16, 1989," box 75, [unprocessed], Durham Schools Collection.

92 "The Governance and Administration Committee of the Merger Issues Task Force," box 5, folder: Merger Issue, 88-89, Durham Schools Collection.

93 "GOAL 2: To ensure local financial support which can adequately and fairly fund 1) needed school system programs and 2) a competitive teacher pay scale without unfairly burdening community taxpayers. "The Governance and Administration Committee of the Merger Issues Task Force," Durham Schools Collection.

${ }^{94}$ For a nuanced examination of this general pattern in a study of the poor suburb of Compton, California, see Emily Straus, Death of a Suburban Dream: Race and Schools in Compton, California (Philadelphia: University of Pennsylvania Press, 2014). On the history of school finance, see Camille Walsh, Racial Taxation: Schools, Segregation, and Taxpayer Citizenship, 1869-1973 (Chapel Hill: University of North Carolina Press, 2018); Ryan, Five Miles Away; Sracic, San Antonio v. Rodriguez and the Pursuit of Equal Education; and Adam R. Nelson, The Elusive Ideal: Equal Educational Opportunity and the Federal Role in Boston's Public Schools, 1950-1985 (Chicago: University of Chicago Press, 2005).

95 "The Governance and Administration Committee of the Merger Issues Task Force," Durham Schools Collection.

96 "Report to the Durham City Board of Education," 7.

97 "The Governance and Administration Committee of the Merger Issues Task Force," Durham Schools Collection. 
population still strongly opposed the merger, which led the county commissioners to avoid a popular vote and instead enforce the merger through the legislature. ${ }^{98}$ Thus, the planned 1989 referendum never took place. The state legislature had long worked to enable school boards to implement mergers without consulting the public, and it revised and reinforced state statute $115 \mathrm{C}-67$, entitled "merger of units in the same county," in 1967, 1969, 1981, and 1991 to increase the authority of school boards to implement mergers. ${ }^{99}$

Resistance also came from people who had previously supported the merger. Patricia Neal, a white woman who had actively advocated for consolidation in 1971, and who had been a member of the Durham County Board of Education in 1978, opposed it in 1989 because, in her opinion, racial balance could no longer be achieved, and merging the two districts would negatively impact county schools:

A merger now would mean that you're going to sacrifice the county kids for however many years it takes to straighten out the mess. I think, eventually, it's probably going to come, but it's going to be at the sacrifice of the county kids, and that's difficult because it's going to be chaos, just chaos. ${ }^{100}$

Teachers were also divided on the issue. A 1989 survey revealed that white teachers in the county schools overwhelmingly opposed merging the districts, whereas city teachers-white and blackfavored the idea. ${ }^{101}$ Black teachers in the county represented only 15 percent of the teaching force and were split on the question, with 57 percent of them favoring the merger. Differences in pay scale played a big part as the suburban district paid its teacher a higher salary than the urban district. ${ }^{102}$

In the face of strong public resistance, why did the merger occur? The fact that the legislature pressured county commissioners across the state to merge city and county districts does not by itself explain the move, since the legislature's position in that regard had been consistent

\footnotetext{
${ }^{98}$ Parrish, "Neglected Common Interests," 58-59.

${ }^{99}$ North Carolina General Statutes, chapter 115C, elementary and secondary education, subchapter III, school districts and units, article 7, organization of schools, $\$ 115 \mathrm{C}-67$, merger of units in same county, 2-3. North Carolina General Assembly, 1991-1992 Session, (Raleigh: North Carolina Session Laws), 200.

${ }^{100}$ Patricia Neal, interview by Kathryn Nasstrom, June 6, 1989, Southern Oral History Program Collection.

101 "Teacher Survey Analysis," in "Facing the Future of Our Schools."

${ }^{102}$ Annual teacher supplements ranged between $\$ 400$ and $\$ 2,100$ in the city system, compared to $\$ 420$ to $\$ 2500$ in the county system. "Teacher Survey Analysis," in "Facing the Future of Our Schools."
} 
since the 1970s. ${ }^{103}$ The passing and implementation of the merger cannot be understood when divorced from the urban development context of the late 1980s and early 1990s. At a time when Raleigh was a more attractive city in the Research Triangle area, Durham lagged behind because of its bad reputation. ${ }^{104}$ Business leaders, like university faculty in the early 1970s, knew that Durham's negative image harmed their recruitment efforts. A couple of decades later, County Commissioner Bell made downtown revitalization his task, with schools playing a crucial part in that project. ${ }^{105}$ As an IBM engineer, he was familiar with corporate interests, and his strong ties to the business community helped him attract major technology companies to the area. ${ }^{106}$

In 1965, IBM was among the first big names to settle in the region. ${ }^{107}$ It validated the entire "industry hunting" project of the RTP, which relied on special tax advantages in the 1960s. ${ }^{108}$ In a 1999 interview, Lauch Faircloth, a US senator and businessman who had worked for the North Carolina Department of Commerce to develop the RTP in the 1970s and 1980s, described how the RTP leadership gradually targeted high-tech industry:

We really concentrated on the high tech, micro-electronics industry. You
can't do everything. There was some heavy industry and the expansion of
our textile industry. We tried to work very closely with the new, modern,
sophisticated textile industry, but the pharmaceuticals and that type of
industry, we worked real hard on [those industries]. ${ }^{109}$

These companies relied on highly skilled employees, with IBM involved in literacy programs and dropout prevention in the region since the 1980s. In 1988, an IBM representative stated, "We believe

${ }^{103}$ Barnette, "A Case Study of the Consolidation of Five North Carolina School Districts."

${ }^{104}$ On the Research Triangle and economic growth in Durham, see Christopher Bradford "The Research Triangle Park as a Regional Employer and Engine of Growth," Urban Economics (2013), https://sites.duke.edu/urbaneconomics/?p=894. 18.

${ }^{105}$ Vaughan and Eanes, "At 31, Bill Bell said, 'If you can't beat'em, join 'em," para.

${ }^{106}$ Rita Thorpe Lamb, Dimensions of Justice: English Teachers' Perspectives on Cultural Diversity (self-pub., 2010), 29.

${ }^{107}$ Mac McCorkle, "History and the 'New Economy' Narrative: The Case of Research Triangle Park and North Carolina's Economic Development," Journal of the Historical Society 12, no. 4 (Dec. 2012), 493.

${ }^{108}$ McCorkle, "History and the 'New Economy' Narrative," 497. Tax breaks for businesses in North Carolina were advertised nationally in the Wall Street Journal. On industry-hunting strategies in the "New South," see Cobb, Selling the New South, 1993.

${ }^{109}$ Lauch Faircloth, interview by Joseph Mosnier, March 22, 1999, Southern Oral History Program Collection. 
if we as a nation are going to survive and IBM is going to survive as a corporation, we have a responsibility to help the educator."110

Bell's rationale for revitalizing downtown Durham was to attract new employees so that the city too could reap the economic benefits of the booming RTP as well as attract new businesses with a well-educated potential workforce coming out of the city schools. ${ }^{111}$ Large companies that settled in the RTP area generated significant revenues through taxes, either for Raleigh or Durham County, depending on their location in the RTP. Clement, chair of the City Board of Education during the 1970s and later a county commissioner, drew direct connections between the locations of businesses outside the city, which she identified as the direct result of urban planning starting in the 1950s, and low city school budgets:

The city has a very small — the city school district, I should say-has a very small tax base as opposed to the county school system. ... It is particularly true here in Durham County because of the Research Triangle Park. Also, because we had a very severe urban renewal program which tore down homes and businesses and what not, and hastened the flight to the suburbs so that the shopping centers and so forth are outside the city. By not moving the city district lines to keep up with the city governmental lines - they are not coterminous - we don't even get the advantage of the shopping centers and businesses like that, that are all on the outskirts of town. ${ }^{112}$

Compared to the Durham city district, the Durham county district benefited tremendously from the arrival of "taxpaying giants." 113

Comparing the fates of Raleigh and Durham further illuminates the crucial role that schools played in the economic development of the two neighboring cities. Both cities held referenda on mergers in the early 1970s and, in a striking parallel, they were both defeated by a three-to-one margin. But in 1974, the Raleigh leadership passed

${ }^{110}$ Luann Nelson and Susan Ross, "Companies Make Schools Their Business," Business, North Carolina 8, no. 2 (Feb. 1988), 28.

${ }^{111}$ Bell compared Durham and Raleigh in 1985, stating: "Durham missed the original boom which hit Raleigh (because) we were slow to get (utilities) in place" Marilyn Weeks, “Triangle' Dream Becomes Multibillion-Dollar Reality," (South Florida) Sun Sentinel, Nov. 9, 1985, 12A. Although not acknowledged in the press, William Bell's wife Marilyn Bell was very active in promoting the merger as well. See "Political Series," Durham School System Merger, Durham School System Merger; and League of Women Voters of Durham, NC, papers, Rubenstein Library, Duke University.

${ }^{112}$ Clement, interview, Aug. 3, 1989.

${ }^{113}$ Barry Yeoman, "How Dividing County School Districts Can Lead to De Facto Segregation," Pacific Standard, Feb. 20, 2018, https://psmag.com/social-justice/ county-school-divisions-lead-to-segregation, para. 2. 
the merger through the legislature anyway, much like the Durham Board of County Commissioners resorted to in the 1990s. ${ }^{114}$ In Raleigh, this was due to local elites with vested interests in sustaining vitality in the downtown area, causing them to bypass the nonbinding popular vote. Historian Karen Benjamin describes the actions of the Raleigh "elite" as part of an effort to "save" downtown Raleigh by eliminating incentives for white outmigration to the suburbs. Contrary to Durham, where opposition had come from both the city and county districts, opposition to a merger in Raleigh largely came from white suburbanites. Business leaders feared that "a blacker, poorer city district surrounded by a whiter, wealthier county district would further damage the economic vitality of downtown." 115 In a fascinating mirror image with Durham, where the referendum vote dictated the actions of the school boards, Raleigh schools actually desegregated at the metropolitan scale, with two-way busing between city and suburbs as a result of the merger.

The state capital disproportionately profited from the economic dynamism of the RTP. Frank Daniels Jr., publisher of the News \& Observer in Raleigh, compared the two cities: "We prospered more than Durham, because school merger helped prevent Raleigh from looking like a doughnut, with a poor, black pocket in the middle."116 Real estate developers favored Raleigh, citing the divisive debates in Durham as deterrent: "Durham's contentious, feuding city and suburban school districts were sharply divided by race and class. They were not as attractive to real-estate developers and young, upscale families as the consolidated, integrated school system that Raleigh built in the mid-1970s." ${ }^{117}$ The comparison highlights how central schools were in shaping the economy of the two neighboring cities.

The stories of Durham and Raleigh thus point to alternative paradigms that developed during the period. "Save the cities, but spare the suburbs" seemed to dominate legal developments in the 1970s, but private actors and urban developers in the region suggest that private forces sometimes framed "saving the city" as a way to boost the economy in a broader context of new economic trends and Cold War

${ }^{114}$ Steve Berg, "Schools Shape Fates of Raleigh and Durham," (Minneapolis) Star Tribune, March 19, 1996, 1A.

${ }^{115}$ Karen Benjamin, "Suburbanizing Jim Crow: The Impact of School Policy on Residential Segregation in Raleigh," Journal of Urban History 38, no. 2 (March 2012), 239.

${ }^{116}$ Steve Berg, "Schools Shape Fates of Raleigh and Durham," (Minneapolis) Star Tribune, March 19, 1996, A10.

${ }^{117}$ Berg, "Schools Shape Fates of Raleigh and Durham." 
competition, even if it meant involving the suburbs. ${ }^{118}$ Just as the RTP symbolizes private and public sector partnership, converging interests between corporate entities and city officials, sometimes embodied by a single individual such as Bell, shaped education policy in the region. ${ }^{119}$

Yet even with new political leadership aligned with business interests, it is not certain that the two districts in Durham would have merged without a simultaneous change in legislation. Until late 1991, county commissioners in North Carolina did not have the authority to merge two school districts without consent from both school boards, and the merger divided Durham residents, especially because of what it meant for political power. ${ }^{120}$ The question of school board representation had always been one of the most divisive issues in the merger debate. ${ }^{121}$ In 1996, a reporter summarized the rationale of county and city residents, who claimed governance on their districts: "Suburbanites wanted no part in solving these problems. Durham's black leaders, who dominated school politics, didn't want a merger either. Maybe their system was bad, they reasoned, but at least it was theirs." 122

Many Durham residents wrote to the North Carolina Superintendent of Public Instruction Bob Etheridge to express their frustration, and their letters capture intense racial divisions. Dan Hill, a white citizen, resented what he perceived to be a "trap" devised by Bell and the legislature to favor black Durhamites: "William V. Bell, Chairman of the Durham County Commissioners recognized a window of opportunity to impose merger upon the Durham voters based on a structure that is favorable to him and the black community." 123 Bell had been elected to the Board of County

${ }^{118}$ Jal Mehta, "The Penetration of Technocratic Logic into the Educational Field," Teachers College Record 115, no. 5 (2013), 1-36.

119 "The Park constituted one of those characteristically American hybrids 'coproduced' by the private and public sectors that defy easy ideological definition," McCorkle, "History and the 'New Economy' Narrative," 519.

${ }^{120}$ About the imminent merger in Durham, a citizen wrote to Governor Hunt in 1993: "Bringing kids together from different neighborhoods causes friction... . I understand that both Durham and Wake Counties plan to reassign students next school year, due to merger and consolidation. I fear the results will not be pleasant, or beneficial." Kenneth F. Maynard to Governor James B. Hunt, Jr., March 25, 1993. box 29, folder: Education: Suggestion: I-M, Governor Hunt Papers, General Correspondence, 1993, North Carolina State Archives.

${ }^{121}$ Kelly Thompson Cochran, "A Familiar Debate Renewed in Durham," News \& Observer (Raleigh, NC), Feb. 29, 1996, A12.

${ }^{122}$ Steve Berg, "Schools Shape Fates of Raleigh and Durham."

${ }^{123}$ Dan Hill to North Carolina State Superintendent, 1991, box 1, folder: State Board of Education, 1991, [unprocessed], Department of Public Instruction, North Carolina State Archives (hereafter cited as State Board of Education). 
Commissioners before the merger law had changed, at a moment when he would not have had the authority to merge the districts without approval of both school district boards.

Some specifically worried about school board elections under a merged system in Durham. Black school board members had historically been elected through district votes. At-large elections would lead to greater white representation, because the entire Durham county population was whiter, even though the school population had a higher percentage of black students. Harris C. Johnson, a black teacher in the city system who led the grassroots American Voter Education Registration Project in Durham, argued:

The Seven Single Member Districts is the only viable plan which will insure equity for all citizens. As a former candidate for the Durham County School Board I am quite aware of how difficult it is for a minority candidate to be elected with the present at-large method for electing School Board members. ${ }^{124}$

Conversely, Charles J. Stewart, the president of Guaranty State Bank in Durham, argued that the business community wanted a mix of district and at-large elections: "Merger of Durham's schools is needed, but not at the expense of racial polarization for the foreseeable future, a factionalized board with all members representing specific districts only, and a dearth of support from citizens who feel forcefully disenfranchised." 125

Residents brought two different lawsuits in an effort to stop the merger's implementation-both cases hinged on voting rights. Plaintiffs in one case alleged gerrymandering in school board representation, arguing that the new board election system was "set up in a fashion that dilutes the white vote." 126 Three white residents argued that the plan for electing members in the new board, which had three members elected from black districts, three from white districts, and one at-large, underrepresented the white population, which was 61 percent overall in the entire Durham area- not noting that the school

${ }^{124}$ Harris C. Johnson to North Carolina State Superintendent, Nov. 30, 1991, State Board of Education.

${ }^{125}$ Charles J. Stewart to N.C. State Board of Education Members, Nov. 29, 1991. State Board of Education.

${ }^{126}$ Peter Schmidt, "2 Suits, Board Rift Strain Durham, N.C., Merger," Education Week, Sept. 20, 1995, https://www.edweek.org/ew/articles/1995/09/20/03nc.h15. html, para. 4. 
population was predominantly black. ${ }^{127}$ In March 1996, the commissioners replaced the plan with at-large elections for the seven members, which, as many understood, weakened the influence of black voters who, since the 1970s, historically had controlled district votes. ${ }^{128}$ Equalizing fiscal resources between the city and county districts not only came at the price of black political control but of proportionate demographic representation on the school board.

Seven parents and a student filed a simultaneous lawsuit to challenge student assignment plans. ${ }^{129}$ The parents were white suburban residents who refused transfers to the city schools. Claiming that the urban, predominantly black student population was best served by black leaders, in black-controlled institutions, an African American senior at Hillside High School was among the plaintiffs, which again captures the merger's racial, political stakes. ${ }^{130}$ Plaintiffs dropped their complaints later in 1995, citing procedural issues. ${ }^{131}$

By the end of 1996, after failed attempts to stop the merger, it seemed that the Durham population had become committed to the new consolidated district, and candidates who had been against the merger lost at the school board election. ${ }^{132}$ Durhamites remained divided on questions of representation and student assignment, and many expressed concerns over the educational consequences for the schools. After years of money and energy spent on structurally altering the districts, the educational situation showed little progress. ${ }^{133}$

In the early 2000s, school board representation remained a sensitive topic in the Durham Public Schools consolidated system, whose school board was predominantly white in a district whose student population was 58 percent African American. ${ }^{134}$ Merging the districts allowed for a more equitable funding formula, however, with both

${ }^{127}$ Jeff Archer, "Racial-Bias Lawsuit Threatens to Disrupt N.C. Board Elections," Education Week, March 13, 1996, https://www.edweek.org/ew/articles/1996/03/13/ 25durham.h15.html.

${ }^{128}$ James Eli Shiffer, "Durham Commissioners Feel Heat," News \& Observer (Raleigh, NC), March 22, 1996, B1.

${ }^{129}$ Bob Edwards, "Durham Schools Bucking Trends, Desegregating Schools," Morning Edition on NPR, Sept. 12, 1995; and Schmidt, "2 Suits, Board Rift Strain Durham, N.C., Merger." para. 6.

${ }^{130}$ Bob Edwards, "Durham Schools Bucking Trends, Desegregating Schools," para. 12.

${ }^{131}$ Kelly Thompson Cochran, "Plaintiffs Retreat in Suit Against Durham Schools," News \& Observer (Raleigh, NC), Dec. 5, 1995, B1.

${ }^{132}$ Kelly Thompson Cochran, "Voters Reject Overhaul of System," News \& Observer (Raleigh, NC), May 8, 1996, A1.

${ }^{133}$ Michele Kurtz, "School System Hopes for Normalcy," News \& Observer (Raleigh, NC), Aug. 26, 1996, B3.

${ }^{134}$ Parrish, "Neglected Common Interests," 85. 
tax bases connected and resources flowing more equitably according to student need. ${ }^{135}$ Old local divisions around funding seemed to fade in the decades following the merger. In 2001, the Durham Committee on the Affairs of Black People led a campaign to oppose a bond proposal to increase funding for schools, arguing that the additional funds would only benefit the building of schools outside of the city. Even though a clear racial demographical separation remained, it was harder to argue that a bond increase would disproportionately benefit white families within a consolidated district. Voters overwhelmingly passed the bond referendum. ${ }^{136}$

\section{Conclusion}

Understanding the history of late-twentieth-century metropolitan education has a bearing in analyzing issues that continue to challenge urban education. In 2001, a commission sponsored by the Durham Public Education Network studied the achievement gap in Durham, mainly the discrepancy between the test scores of white children and students of color: 90 percent of white and Asian students performed at or above grade level in reading and math, compared to 60 percent of African American students. ${ }^{137}$ The Network's report included the following statement in bold, capital letters: "The achievement gap is no one's fault, but it's everyone's responsibility!" 138 This sentence suggests that the achievement gap has no history, yet historians have long worked against this notion. The phrase fails to convey how stakeholders with specific motivations for racial and fiscal isolation had maintained and drawn lines that would promote particular agendas. These divisions created exclusionary, centrifugal hubs of resources that contributed to reinforcing the difficulties of the inner city schools. ${ }^{139}$ Erasing this history runs the risk of attributing differences in achievement to essential characteristics. ${ }^{140}$

${ }^{135}$ The legacy of the merger remains a contested issue. Yeoman, "How Dividing County School Districts Can Lead to De Facto Segregation," para 30.

${ }^{136}$ Parrish, "Neglected Common Interests," 86.

137 "Closing the Achievement Gap Through Community Action" Spring 2001, box 4, "Durham Public Schools: Education+Testing" sub folder: Closing the Achievement Gap, Theresa El-Amin papers, Rubenstein Rare Book \& Manuscript Library, Duke University.

138 "Closing the Achievement Gap Through Community Action."

${ }^{139}$ Richard Briffault uses the expression "centrifugal force" to describe the property tax-based system of school financing. "The Role of Local Control in School Finance Reform," Connecticut Law Review 24, no. 3 (Spring 1992), 773-812.

${ }^{140}$ On the racial bias of standardized testing, see Stephen Jay Gould, The Mismeasure of Man (New York: W. W. Norton, 1996); and Nicholas Lemann, The 
The black population in Durham faced a difficult compromise between equalizing resources and retaining political power over the city schools. Thus the difficulties urban schools in Durham faced are not solely ascribable to "white flight" and desegregation policies. ${ }^{141}$ These sacrifices stemmed from persistent racist financial policy and administrative choices, such as "city-out" legislation, that had advantaged white suburbanites since the 1950s, and beyond.

Although the 1991 merger worked to erase entrenched boundaries between city and county schools, it failed to unravel them completely. Moreover, starting in the 1990s, many affluent families opted out of the traditional public school system and instead chose private academies and charter schools. ${ }^{142}$ Even within the new Durham Public Schools system, discrepancies still exist between affluent and poor areas. One outraged blogger in 2008 asked, "Why in hell do we tolerate a world in which there are schools with $70 \%$ and $90 \%$ free and reduced lunch rates? Why do we tolerate an educational system that segments out schools ... to be warrens of the poor alone?"143 The merger failed to undermine the concentration of poverty in city schools, and did not end racial segregation. In 2001, Rogers-Herr Middle School, located in the city's southwest, was 74 percent black, 10 percent Latinx, and 16 percent white. ${ }^{144}$ In 2018, its population was 59.8 percent black and 16.2 percent Latinx. ${ }^{145}$ Rogers-Herr is located just two thousand feet from the private Durham Academy Middle School, which in 2018 was 73.6 percent white. ${ }^{146}$

Big Test: The Secret History of the American Meritocracy (New York: Farrar, Straus and Giroux, 2000).

${ }^{141}$ Erika Kitzmiller makes this argument about Germantown High School in Philadelphia. See The Roots of Educational Inequality: Germantown High School 19072013 (Philadelphia, University of Pennsylvania Press, forthcoming).

${ }^{142} \mathrm{~A}$ report by Duke professors showed that white parents preferred schools that were less than 20 percent black, and that these parents have increasingly chosen charter schools since the 1990 s to avoid traditional public schools. Helen F. Ladd, Charles T. Clotfelter, and John B. Holbein, "The Growing Segmentation of the Charter School Sector in North Carolina," Education Finance and Policy 12, no. 4 (Fall 2017), 536-63.

${ }^{143}$ Kevin Davis, "Creekside Reassignment: On Schools Being Good by Being Well(-off)," Bull City Rising, Jan. 28, 2008, http://www.bullcityrising.com/2008/01/ creekside-reass.html, para. 22.

${ }^{144}$ Parrish, "Neglected Common Interests," 85.

145 "Rogers-Herr Middle School in Durham, North Carolina," USA School Info, http://www.usaschoolinfo.com/school/rogers-herr-middle-durham-north-carolina. 66525 /enrollment.

146“Durham Academy in Durham, North Carolina," USA School Info, http://www. usaschoolinfo.com/school/durham-academy-durham-north-carolina.126721/ enrollment. 
In an educational landscape increasingly fragmented by the advent of school choice, school district boundaries are still very much a live political and legal issue. In 2017, Republican members of the North Carolina legislature introduced a bill aimed at splitting consolidated districts into smaller units. ${ }^{147}$ Law professor Derek Black, who has written extensively on the inequitable effects of economically isolated school districts, denounced these state efforts to dismantle "the lynchpin of equality and integration-the county wide school system structure," and to create "a thousand isolated pockets." 148 Dismantling countywide systems would lead places like Durham to reverse consolidation and thereby encourage racial and economic separation, not only between the city and its surrounding suburbs but perhaps even smaller units of racially, socioeconomically, and financially isolated school districts. ${ }^{149}$

${ }^{147}$ General Assembly of North Carolina, Session 2017, House Bill 704, "An Act to Establish the Joint Legislative Study Committee on the Division of Local School Administrative Units," https://www.ncleg.net/Sessions/2017/Bills/House/PDF/ H704v1.pdf.

${ }^{148}$ Derek Black, "How Far Will North Carolina Go to Dismantle Integration and Equality in Its Schools?," Education Law Prof Blog, April 11, 2018, http://lawprofessors. typepad.com/education_law/2018/04/how-far-will-north-carolina-go-to-dismantle-integration-and-equality-in-its-schools.html, para. 3

${ }^{149}$ Yeoman, "How Dividing County School Districts Can Lead to De Facto Segregation," para. 9. 